\author{
Andrzej MOROZ \\ Uniwersytet Mikołaja Kopernika w Toruniu \\ amoroz@umk.pl \\ http://orcid.org/0000-0002-0414-4832
}

\title{
TERMINOLOGIA PRAWNA W ASPEKCIE NORMATYWNYM
}

\section{WPROWADZENIE}

Przedmiotem rozważań $\mathrm{w}$ niniejszym tekście jest w gruncie rzeczy pokaźny zbiór leksykalny, na który składa się terminologia tekstów prawnych. W punkcie wyjścia na tak wyznaczony zbiór nakłada się jedynie dwa istotne ograniczenia. Przede wszystkim - akceptując utrwaloną już w tradycji opozycję języka prawnego i prawniczego ${ }^{1}$ (Wróblewski 1948, Zieliński 1999, Malinowski 2006, Petzel 2011) i pomijając w związku z tym również języki okołoprawne - rozważaniami obejmuje się tu wyłącznie pojęcia prawne, czyli te wyrażenia językowe, którym przypisano w trakcie procedur legislacyjnych definicje legalne. Po drugie, poza polem obserwacji pozostawia się ciągi, których status językowy jest ściśle powiązany z subkodem prawnym, czyli takie jednostki, które - przy zachowaniu synchronicznej perspektywy opisu (zob. Saussure, Ferdinand 2004) - funkcjonują jedynie jako wyrażenia tej odmiany języka. Dotyczy to między innymi terminów łacińskich, np. vacatio legis czy fideiussor, lub utworzonych historycznie na potrzeby prawa i tylko w tym kodzie funkcjonujących, np. asesor czy wadium (zob. Zajadło 2014, Żurowski 2015). To wyłączenie dotyczy także jednostek, dla których nie da się we współczesnym języku polskim wskazać bazy motywacyjnej.

1 Pojęcie języka pojawia się $\mathrm{w}$ tym opisie nieformalnie $\mathrm{z}$ uwagi na konwencję wykorzystywania go szczególnie w opracowaniach z zakresu prawa. Zgodnie z wyrażonym wcześniej stanowiskiem (zob. Gębka-Wolak, Moroz 2019) tekstom prawnym nie przypisuje się odrębności językowej, a jedynie uznaje się je za odmianę języka ogólnego. 
Przyjmuje się także, że zarówno sposób wyznaczenia analizowanego zbioru wyrażeń, jak i wskazane ograniczenia są motywowane normatywnym celem prowadzonych rozważań. Istotne jest bowiem określenie odrębności w sposobie funkcjonowania terminologii prawnej w stosunku do jednostek subkodu ogólnego. Aby zdać sprawę z tego faktu, konieczne jest porównanie leksyki prawnej $\mathrm{z}$ odpowiadającą jej pod względem formy i znaczenia leksyką ogólną, do której włącza się również bazy motywacyjne poszczególnych terminów prawnych. Tym samym uznaje się, że brak odpowiednika w subkodzie ogólnym, względnie brak synchronicznej motywacji istnienia danego terminu porównanie takie uniemożliwia. Przeprowadzenie takiego porównania pozwala z kolei odpowiedzieć na pytanie, czy funkcjonowanie terminów prawnych jest zgodne z normą współczesnej polszczyzny. Nim jednak podjęty zostanie główny wątek rozważań, warto przyjąć kilka założeń natury ogólnej.

1.1. Pierwszy problem pojawiający się podczas analizy tytułowego zagadnienia wynika z nie do końca jasno sprecyzowanego pojęcia "termin". $W$ gruncie rzeczy w literaturze przedmiotu zderzają się $w$ tej materii dwa stanowiska. Pierwsze wynika z tezy Stanisława Gajdy, który twierdzi, że termin to ,,jednostka leksykalna spełniająca funkcję znaku profesjonalnego pojęcia, a więc rodzaj użycia, a nie specjalny typ jednostki leksykalnej" (Gajda 1990: 38, por. też Hałas 1995: 5, Choduń 2007: 124). Na tej zasadzie przypisuje mu się takie własności, jak sfera użycia, definicyjność, systemowość, jedno-jednoznaczność, nieekspresywność (zob. Gajda 1990: 39). W opozycji do takiego rozumienia terminu pozostaje propozycja Macieja Grochowskiego, który uznaje termin za „ciąg elementów diakrytycznych, reprezentujących w języku L na mocy przyjętej w nim konwencji określone pojęcie i odnoszący się do obiektu należącego do obszaru zainteresowań danej zbiorowości Z posługującej się tym językiem" (Grochowski 2017: 13). Obie przytoczone definicje różni przede wszystkim status językowy wyrażenia specjalistycznego. W pierwszym wypadku zwraca się bowiem uwagę na niepodzielność i funkcję znaczącą takiego obiektu, o czym decyduje przede wszystkim uznanie go za jednostkę leksykalną. W przeciwieństwie do takiego stanowiska Grochowski uwypukla denotatywną rolę terminu, wskazując na reprezentowanie przez niego określonego pojęcia. Elementem wspólnym z kolei jest ograniczony zasięg terminu, zawężony do profesjolektu i odnoszący się do zainteresowań określonej zbiorowości. Ważnym spostrzeżeniem $\mathrm{w}$ tej materii jest natomiast uznanie konwencjonalnego sposobu wiązania tre- 
ści i formy terminu, na co zwraca uwagę Maciej Grochowski. Przyjęte $\mathrm{w}$ niniejszej pracy rozumienie terminu jest $\mathrm{w}$ gruncie rzeczy sumą obu zaproponowanych definicji. Uznaje się bowiem, że pojęcie to jest wyznaczane zarówno poprzez własności konotacyjne - znaczenie przypisywane na mocy definicji legalnej - jak i denotacyjne - wskazywanie na określone fakty w rzeczywistości pozajęzykowej. Jest więc termin jednostką leksykalną tworzoną arbitralnie zgodnie z pewną konwencją i pełniącą funkcję nazywającą w ograniczonej zbiorowości użytkowników.

1.2. Inny problem związany z opisem leksyki prawnej wynika z ogromnej różnorodności wyrażeń pełniących określone funkcje w tej odmianie polszczyzny. Prawdą jest, że większość opracowań z tego zakresu bierze za cel próbę ustalenia zbioru jednostek, dla których funkcja prawna (nazywanie faktów związanych ze stanowieniem bądź stosowaniem prawa) jest funkcją podstawową. $W$ tym kierunku idą rozważania zarówno prawników (zob. Chodun 2006, Malinowski 2006), jak i językoznawców (zob. Hałas 1995, Łapa 2015, Lizisowa 2016). Inna rzecz, że jak prawnicy koncentrują się głównie na opisie leksyki prawnej, tak językoznawcy zwracają szczególną uwagę na funkcje takich wyrażeń (zob. Łapa 2015) lub modyfikacje wyrażeń ogólnych, głównie znaczeniowe (zob. Hałas 1995). Nie zmienia to jednak faktu, że leksyka pojawiająca się w strukturze aktów prawnych nie jest jednolita (zob. Czelakowska, Kubicka 2017), a tym samym przy analizie problemu normatywnego użycia wyrażeń w prawie warto sobie $\mathrm{z}$ tego faktu zdawać sprawę. $Z$ tego też powodu w opracowaniu tym przyjmuje się istnienie pięciu klas obiektów leksykalnych występujących $w$ tekstach prawnych, a mianowicie podstawowych wariantów jednostek języka, np. ktoś wykonuje coś, systemowych wariantów jednostek języka, np. popetnienie czegoś, pozasystemowych wariantów jednostek języka, np. ściganie o, legalnych jednostek terminologicznych, np. osoba najbliższa, specjalnych jednostek terminologicznych, np. alimenty (zob. Gębka-Wolak, Moroz 2019: 98-104). Z tego zestawu jedynie dwie ostatnie klasy spełniają definicję terminu, one to więc będą przedmiotem rozważań $\mathrm{w}$ tym opracowaniu.

1.3. Pozostaje do rozstrzygnięcia drugi aspekt rozważań, wskazany tytułem niniejszego artykułu. Otóż nie jest rzeczą prostą ustalenie, czym jest normatywność pewnych struktur językowych, ich użycie dopuszczone przez normę. Prawdą jest bowiem, że pojęcie normy zazwyczaj ujmuje się w kategoriach abstrakcyjnych, uznając, że należą do niej „te elementy języka i wypowiedzi [norma wzorcowa - AM], które są uży- 
wane świadomie, z poczuciem ich wartości semantycznej i stylistycznej, a pozostają $\mathrm{w}$ zgodzie $\mathrm{z}$ tradycją językową, regułami gramatycznymi i semantycznymi polszczyzny oraz tendencjami rozwojowymi, które można w niej obserwować" (Markowski 2005: 32). Takie podejście w punkcie wyjścia krzyżuje dwie perspektywy opisu normy, a mianowicie obiektywną - zgodność z regułami - oraz subiektywną - świadome posługiwanie się językiem. Wydaje się, że rozdzielenie obu perspektyw orzekania o poprawności określonych struktur jest czynnością niezwykle istotną. Z tego też powodu intuicyjne orzeczenia będą $w$ tym opracowaniu ujmowane w kategoriach akceptowalności, przez którą rozumie się subiektywną ocenę dopuszczalności określonej konstrukcji lub wyrażenia, „możliwość jego zdekodowania w określonej sytuacji komunikatywnej” (Gębka-Wolak, Moroz 2009: 127). W opozycji do niej poprawność będzie sądem wynikającym wprost z analizy wyrażenia i wiąże się „z możliwością przypisania mu interpretacji w obrębie zdefiniowanego modelu referencyjnego" (Gębka-Wolak, Moroz 2009: 129). W tej materii sąd taki ma zawsze charakter obiektywny. Ostatecznie wydaje się uzasadnione, aby pojęcie normy ujmować w kategoriach poprawności wyżej zdefiniowanej. Byłaby ona bliska tzw. normie skodyfikowanej, choć znacznie poza nią wychodząca, gdyż o spełnianiu wymagań normy decydowałaby dodatkowo zgodność $\mathrm{z}$ modelem opisu języka.

\section{CECHY TERMINOLOGII PRAWNEJ}

Zgodnie z przyjętym założeniem przedmiotem obserwacji są wyrażenia terminologiczne, które w określonym akcie prawnym zostały jednoznacznie zdefiniowane poprzez nadanie im definicji legalnej. Informacje o tym fakcie znajdują się bądź w początkowej części kodeksu, np. chodnik - 'część drogi przeznaczona do ruchu pieszych' (KD), bądź też w dowolnej jego części, np. za konsumenta uważa się osobę fizyczna dokonująca z przedsiębiorca czynności prawnej niezwiązanej bezpośrednio z jej działalnościa gospodarcza lub zawodowa (KC). W drugim wypadku sama struktura definicji nie jest wskazana w sposób jawny. Materialną podstawą poszukiwań jest z kolei siedem kodeksów karnego modułu prawnego, a mianowicie Kodeks karny, Kodeks wykroczeń, Kodeks karny wykonawczy, Kodeks karny skarbowy, Kodeks postępowania karnego, Kodeks postępowania w sprawach o wykroczenia oraz Kodeks rodzinny i opiekuńczy. Wskazane akty prawne były 
poddane analizie za pomocą narzędzia Korpusomat (Kieraś ... Ogrodniczuk 2018). Celem prowadzonych obserwacji jest z kolei zestawienie cech terminów występujących $\mathrm{w}$ tekstach prawnych $\mathrm{z}$ odpowiadającymi im pod względem formy i znaczenia wyrażeniami polszczyzny ogólnej. Efektem takiego zestawienia będzie z kolei wniosek dotyczący normatywności funkcjonowania wyrażeń w tekstach prawnych.

2.1. Analiza zebranego materiału wskazuje jednoznacznie na fakt, że wyrażenia terminologiczne występujące w kodeksach nie stanowią zbioru jednolitego. Można wśród nich znaleźć przede wszystkim struktury jednosegmentalne, zarówno derywowane, por.

(1) Odpowiada za sprawstwo nie tylko ten, kto wykonuje czyn zabroniony sam albo wspólnie $i w$ porozumieniu $z$ inna osobq, ale także ten, kto kieruje wykonaniem czynu zabronionego przez inna osobe lub wykorzystujac uzależnienie innej osoby od siebie, poleca jej wykonanie takiego czynu. KK 18,1

(2) Odpowiada za pomocnictwo, kto w zamiarze, aby inna osoba dokonała czynu zabronionego, swoim zachowaniem ułatwia jego popetnienie, w szczególności dostarczając narzędzie, środek przewozu, udzielając rady lub informacji; odpowiada za pomocnictwo także ten, kto wbrew prawnemu, szczególnemu obowiązkowi niedopuszczenia do popetnienia czynu zabronionego swoim zaniechaniem ułatwia innej osobie jego popełnienie. KK 18,3

jak i niederywowane, por.

(3) Rozkazem jest polecenie określonego działania lub zaniechania wydane służbowo żotnierzowi przez przełożonego lub uprawnionego żotnierza starszego stopniem. KK 115,18

(4) Określenie "dyrektor" oznacza również zastępce dyrektora aresztu śledczego lub zakładu karnego, a także funkcjonariusza lub pracownika zakładu karnego lub aresztu śledczego, który został upoważniony do zastępowania dyrektora zakładu karnego lub aresztu śledczego podczas jego nieobecności. KW 242, 4a

Naturalnym sposobem konstruowania terminów prawnych jest jednak ich konstrukcyjność. Zdecydowana większość wyrażeń zdefiniowanych w kodeksach to ciągi wielosegmentowe, np. 
(5) Z chwila zatarcia skazania uważa sie je za niebyłe; wpis o skazaniu usuwa się z rejestru skazanych. KK 106

(6) Przez pojęcie nadzoru nad korespondencja rozumie się otwarcie listu i sprawdzenie jego zawartości. KW 242,6

Wszystkie wymienione grupy terminów spełniają w stopniu całkowitym warunki sformułowane $\mathrm{w}$ założeniach niniejszego opracowania. One tym samym staną się podstawą szczegółowej analizy.

2.2. Jest rzeczą oczywistą, że w krótkim opracowaniu nie uda się zdać sprawy z wszystkich aspektów funkcjonowania terminów prawnych, nawet jeżeli ograniczymy się do kwestii normy. Tym samym przedmiotem charakterystyki warto objąć jedynie wybrane jednostki. Ich porównanie z ogólnymi odpowiednikami powinno z kolei wskazać określone tendencje $\mathrm{w}$ tym zakresie. $\mathrm{Z}$ tego też powodu oglądowi zostaną poddane trzy - różne pod względem strukturalnym - pojęcia, a mianowicie: darowizna, pomocnictwo, zatarcie skazania, por.

(7) W umowie darowizny albo w testamencie można zastrzec, że przedmioty przypadające dziecku z tytułu darowizny lub testamentu nie będa objęte zarzadem sprawowanym przez rodziców. KRiO

(8) Karę za podżeganie lub za pomocnictwo wymierza się w granicach zagrożenia przewidzianego dla danego wykroczenia. KW 14,3

(9) Sąd może na wniosek skazanego zarządzić zatarcie skazania już po upływie 5 lat... KK 107,2

Pierwszemu $\mathrm{z}$ analizowanych tu terminów przypisuje się $\mathrm{w}$ prawie następujące znaczenie: przez umowę darowizny darczyńca zobowiązuje się do bezpłatnego świadczenia na rzecz obdarowanego kosztem swego majątku (KC 888), a on sam charakteryzuje się ograniczoną łączliwością. W jego kontekście lewostronnym pojawia się bowiem zazwyczaj struktura spójnikowa, dołączająca analizowany termin do ciągu współrzędnego, por. dziedziczenie, zapis lub darowizna, lub też bezpośredni nadrzędnik dystrybucyjny należący do zamkniętego w gruncie rzeczy zbioru, por. umowa darowizny, tytuł darowizny. W kontekście prawostronnym z kolei występują struktury wskazujące na źródło darowizny $-z$ majątku wspólnego lub na jej odbiorcę - na rzecz innych osób. Oba elementy nie mają jednak 
charakteru obligatoryjnego, a w wielu wypadkach sam termin funkcjonuje w izolacji. Taki stan rzeczy jest jednak typowy dla ciągów terminologicznych.

Gerundium pomocnictwo - drugi z wybranych do analizy terminów - bywa definiowany w szerokim kontekście czynu zabronionego, a mianowicie odpowiada za pomocnictwo, kto w zamiarze, aby inna osoba dokonała czynu zabronionego, swoim zachowaniem ułatwia jego popetnienie, w szczególności dostarczając narzędzie, środek przewozu, udzielając rady lub informacji; odpowiada za pomocnictwo także ten, kto wbrew prawnemu, szczególnemu obowiazkowi niedopuszczenia do popetnienia czynu zabronionego swoim zaniechaniem ułatwia innej osobie jego popetnienie (KK 18,3). Pojęcie to - podobnie jak analizowane wcześniej - również zazwyczaj pojawia się w strukturach bezpodrzędnikowych, co jest odstępstwem od ogólnojęzykowych cech wyjściowego czasownika pomóc. Cechy takie są jednak typowe dla wielu terminów prawnych (zob. Moroz 2014). Sam termin z kolei zasadniczo występuje w dwóch strukturach - albo jako element szeregu współrzędnego wraz z pojęciami usiłowanie, podżeganie, gdzie stanowi element podmiotu szeregowego, por.

(10) Usiłowanie oraz podżeganie i pomocnictwo sq karalne. KW 133,2

albo też w pozycji poprzyimkowej, zawsze po przyimku za-odpowiada za pomocnictwo, odpowiedzialność za pomocnictwo, kara za pomocnictwo. Wydaje się więc, że w wypadku tego wyrażenia problem normatywny wiąże się zarówno z budową wewnętrzną terminu, jak i jego łączliwością.

Zatarcie skazania $\mathrm{z}$ kolei rozumie się w prawie w sposób następujący, otóż z chwila zatarcia skazania uważa się je za niebyłe; wpis o skazaniu usuwa się z rejestru skazanych (KK 106). Jest rzeczą interesującą, że - w przeciwieństwie do typowych terminów wielosegmentowych - ciąg taki nie jest strukturą powiązaną wewnętrznie w sposób konieczny. W analizowanych kodeksach poszczególne człony terminu nie muszą występować bezpośrednio obok siebie, jak również nie jest konieczne, aby pomiędzy nimi zachodziła bezpośrednia relacja zależności, por.

(11) Skazanie ulega zatarciu z mocy prawa z upływem 6 miesięcy od zakończenia okresu próby. KK 76,1

(12) Nie podlega zatarciu skazanie na karę pozbawienia wolności bez warunkowego zawieszenia jej wykonania... KK 106a 
Warto zauważyć, że stabilna struktura ciągu - istotna w wypadku uznania takiego bytu za jednostkę leksykalną - pojawia się zazwyczaj przy użyciach czynnych: sąd zarzadza zatarcie skazania, w przedmiocie zatarcia skazania orzeka są, podczas gdy użycia bierne preferują zazwyczaj struktury niezależne, skazanie ulega zatarciu, skazanie nie podlega zatarciu itp. Sam komponent terminologiczny pojawia się zazwyczaj w pozycji dopełnieniowej - sad orzeka zatarcie skazania. Pozycja podmiotowa jest natomiast preferowana $\mathrm{w}$ strukturach o postaci zatarcie skazania następuje z mocy prawa. Budowa wewnętrzna tego terminu nie budzi jednak większych kontrowersji. Mamy bowiem do czynienia z ciągiem dwóch rzeczowników gerundialnych, z których jeden - z uwagi na powiązania zależnościowe - występuje $\mathrm{w}$ dopełniaczu. Z odstępstwami dotyczącymi takiej struktury mamy do czynienia głównie w scharakteryzowanych wyżej ciągach biernych - skazanie ulega zatarciu. Inna rzecz, że istnienie takich wyrażeń może skłaniać do rewizji sądu o spełnianiu przez wyrażenia terminologiczne wszystkich cech jednostki języka.

\section{CECHY ANALOGONÓW OGÓLNYCH}

Wszystkie analizowane wyżej terminy mają swoje odpowiedniki w polszczyźnie ogólnej. Wśród nich są naturalnie takie, które we właściwym znaczeniu i formie są notowane $\mathrm{w}$ słownikach, $\mathrm{np}$. darowizna, inne $\mathrm{z}$ kolei zostały utworzone w sposób co prawda niestandardowy, ale zgodny $\mathrm{z}$ istniejącymi modelami gramatycznymi - pomocnictwo (alternatywna forma ogólnopolskiej pomoc) - bądź też stanowią regularną konstrukcję, której nadano funkcje jednostkowe w procesie definiowania, np. zatarcie skazania. Podejmijmy zatem próbę porównania cech i funkcji poszczególnych obiektów.

3.1. Wielki słownik języka polskiego (zob. Żmigrodzki ... Węgrzynek 2018) pojęciu DAROWIZNA przypisuje dwa znaczenia - odnoszące się do samej czynności oraz odnoszące się do obiektu danej czynności. $\mathrm{Z}$ uwagi na fakt, że w systemach prawnych uwypukla się czynnościowy charakter tego terminu, jedynie to znaczenie będzie przedmiotem opisu. Tym samym jednostkę taką definiuje się jako 'przekazanie, na mocy odpowiedniej umowy, pieniędzy, przedmiotów lub innych dóbr materialnych' (WSJP). Przede wszystkim w opisie słownikowym nie mamy wskazanego zawężenia do subkodu prawnego, co może wskazywać na ogólne 
znaczenie tej jednostki. Prócz tego wskazuje się na motywację odczasownikową analizowanego rzeczownika - darować. Samej jednostce darowizna nie przypisuje się co prawda specjalnych wymagań, ale są one interpolowane na podstawie wymagań bazowego czasownika $-\mathrm{Rz}_{\mathrm{os}}+d a$ rować + KOMU/CZEMU + CO. Interesująco przedstawia się $\mathrm{w}$ tej materii transformacja formalna, której podlega sposób realizacji odbiorcy czynności, gdyż zamiast struktury celownikowej pojawiają się przyimki wielosegmentowe na cele publiczne, na rzecz kogoś. Pozycja biernikowa co oczywiste - podlega transformacji na dopełniacz darowizna aparatury, nieruchomości. Dodatkowo w bezpośrednim sąsiedztwie mogą pojawiać się pozycje dla kogoś, kto daje darowiznę, lub wskazanie celu darowizny $^{2}$, por.

(13) Dom w Białymstoku jest na mnie, bo to darowizna od ojca. NKJP

(14) Kościót musi przedstawić umowę darowizny z przeznaczeniem na cele kultowe, charytatywne i oświatowo-wychowawcze. NKJP

Jak można więc sądzić, różnice w prawostronnej łączliwości analizowanego terminu w ciągach ogólnej polszczyzny i polszczyzny prawnej dotyczą dwóch elementów, a mianowicie szerszego użycia bezkontekstowego $\mathrm{w}$ tekstach prawnych oraz dominacji - również $\mathrm{w}$ tych tekstach - struktury o kształcie darowizna z (majątku wspólnego \|n nieznanych źódet $\|$ funduszu reklamowego). W tekstach prawnych wyrażenie $z$ CZEGO wskazuje na źródło darowizny, które w tekstach ogólnych jest określane za pomocą wyrażenia od KOGO.

W kontekście prawostronnym z kolei zasadniczo pojawiają się ciągi czasownikowe, $\mathrm{z}$ tym że liczba elementów takiego zbioru $\mathrm{w}$ tekstach prawnych jest mocno ograniczona. I jak darowiznę w polszczyźnie ogólnej można odliczyć, przekazać, wpłacać, przekazywać, dokumentować i in., tak w tekstach prawnych mówi się jedynie o jej nabyciu, przyjęciu, dokonywaniu, wykonaniu. Wydaje się jednak, że żadna ze wskazanych list nie jest ograniczona, a tym samym pozycję lewostronną otwieraną przez termin darowizna należy uznać za niezamkniętą. Warto też zauważyć, że jednostki na obu listach są różne, co świadczy o odrębnych sposobach budowania kolokacji.

2 Przykłady polszczyzny ogólnej są podawane za Narodowym Korpusem Języka Polskiego (zob. Przepiórkowski ... Lewandowska-Tomaszczyk 2012). 
3.2. Problem odmienności takich gerundialnych terminów, jak pomocnictwo, sprawstwo czy usiłowanie, był już przedmiotem obserwacji w literaturze przedmiotu (zob. Moroz 2014, Gębka-Wolak, Moroz 2019). Zwracano tam uwagę zarówno na specyficzną budowę takich form, jak również ich eliptyczność. W tym miejscu warto tym samym uzupełnić wcześniejsze rozwiązania, wskazując na cechy pomijane. Otóż Wielki słownik języka polskiego wypowiada się jednoznacznie na temat prawnej kwalifikacji komponentu pomocnictwo, definiując go jako praw. 'przestępstwo polegające na umyślnym pomaganiu komuś przy popełnianiu przez tego kogoś innego przestępstwa' (WSJP). Przede wszystkim wskazuje on wyraźnie na obligatoryjną lewostronną i fakultatywną prawostronną (do CZEGO ॥ przy CZYM $\| w$ CZYM) łączliwość tego rzeczownika. W kontekście lewostronnym pojawia się tu rzeczownik zarzut (zarzut pomocnictwa) lub struktura oskarżony o (oskarżony o pomocnictwo), por.

(15) Przedstawiono mu zarzut pomocnictwa w napadzie. NKJP

(16) Oskarżono go o pomocnictwo przy próbie napadu na konwój z pieniędzmi... NKJP

Pomimo zgodności definicji i zakresu funkcjonowania terminu pomocnictwo między użyciami w polszczyźnie ogólnej i prawnej istnieją pewne różnice. Przede wszystkim w tekstach prawnych w kontekście lewostronnym pojawia się najczęściej struktura odpowiada za, rzadziej kara za, względnie wewnątrzzdaniowy kontekst lewostronny jest pusty. Co więcej, analizowane kodeksy nie notowały wcale wymienionych w słownikach przykładów wypełniania kontekstu prawostronnego. W takich wypadkach albo pojawiało się orzeczenie - przy realizacjach podmiotowych pomocnictwo jest karalne, pomocnictwo zachodzi, albo też kontekst ten pozostaje niewypełniony. Jak się więc wydaje, również $w$ analizowanym przypadku mamy do czynienia z rozbieżnościami dotyczącymi funkcjonowania obu struktur terminologicznych.

3.3. Wielki słownik jezzyka polskiego nie notuje z kolei ostatniego z przytoczonych terminów, co więcej nie pojawia się również - jako hasło forma gerundialna, a tym samym analizując cechy normatywne interesującego nas obiektu, musimy się odwołać do czasownika zatrzeć będącego podstawą rzeczownika zatarcie. Słownik przypisuje mu 6 znaczeń, z czego nas interesować będą w gruncie rzeczy trzy: ZATRZEĆ 1 - 'uczynić niewidocznym', ZATRZEĆ 2 - 'osłabić wymowę lub znaczenie czegoś' oraz 
ZATRZEĆ 3 - 'usunąć z pamięci'. Struktura czasowników jest zbliżona, co charakteryzuje schemat _ + zatrzeć + CO. ZATRZEĆ 2 może dodatkowo łączyć się fakultatywnie z frazą CZYM, a ZATRZEĆ 3 z frazą w CZYM. Tym samym - pod względem formalnym - termin zatarcie skazania jest gramatyczną transformacją przytoczonego schematu, gdzie na miejscu frazy biernikowej pojawia się dopełniacz. Łączliwość przytoczonych jednostek jest również zbliżona. Wskazuje bowiem głównie na rzeczownikowy kontekst prawostronny - szczególy, wspomnienia, dowody, podziały, zbrodnię. Ten element nas jednak nie interesuje $z$ uwagi na fakt, że jest integralną częścią analizowanego terminu. Ona z kolei lewostronnie łączy się w polszczyźnie ogólnej z czasownikami ulegać, podlegać, skutkować, umożliwiać, zarządzić oraz z rzeczownikami instytucja, przesłanka, termin do. Z kolei w kontekście prawostronnym wystąpią tu wyrażenia przyimkowe za przestępstwo, przez sąd, z mocy prawa. Interesujący jest również przykład ciągu z pluralną formą rzeczownika skazanie, co w tekstach prawnych jest stosunkowo rzadkie, por.

(17) Rozdz. 5 określa [...] skutki ukarania i zatarcia skazań. NKJP

(18) Jeżeli sprawcę skazano za dwa lub więcej nie pozostajacych w zbiegu przestępstw, [...], dopuszczalne jest tylko jednoczesne zatarcie wszystkich skazań. KK 108

Porównanie funkcjonowania analizowanego terminu $\mathrm{w}$ tekstach prawnych i tekstach polszczyzny ogólnej wskazuje na fakt, że subkod prawny preferuje użycia podmiotowe, co wyklucza kontekst lewostronny, i rzadziej dopełnieniowe, por. zatarcie skazania następuje, zatarcie skazania nie może nastapić, sąd orzeka zatarcie skazania, sąd może zarządzić zatarcie skazania. W kontekście prawostronnym pojawia się z kolei jedynie formuła $z$ mocy prawa, choć i tak częściej będziemy mieli do czynienia z ciągiem zatarcie skazania następuje z mocy prawa, gdzie wskazany związek bezpośredni nie zachodzi.

\section{PROCEDURY NORMATYWIZACJI}

Wyżej przeprowadzone obserwacje wskazują jednoznacznie na złożoność procesu normatywizacji w wypadku tekstów prawnych. Jest bowiem rzeczą oczywistą, że niemożliwe jest bezpośrednie zastosowanie 
do nich ani wzorcowego, ani użytkowego poziomu normy $\mathrm{z}$ uwagi na fakt, że zostały one wypracowane na materiale polszczyzny ogólnej. Wydaje się więc, że budowanie procedur poprawnościowych winno opierać się na nieco innych kryteriach. Przede wszystkim jednak należy zdać sobie sprawę z faktu, że relacje pomiędzy kodem ogólnym a subkodem prawnym opierają się na jednym $z$ trzech typów zależności.

4.1. Przede wszystkim możliwa jest - prawdopodobnie najczęstsza relacja zgodności obu kodów [OGÓLNY = PRAWNY]. Wtedy zarówno cechy formalno-znaczeniowe danego wyrażenia, względnie konstrukcji, jak i ich łączliwość zewnętrzna - zdolność budowania kolokacji - są tożsame. $\mathrm{W}$ takim wypadku oceny poprawnościowe są $\mathrm{w}$ gruncie rzeczy proste, gdyż zmierzają do zastosowania modelu normatywnego znanego z polszczyzny ogólnej na gruncie polszczyzny prawnej. Przykłady takiego stanu można by mnożyć. Taki charakter ma np. wyrażenie kara. Zostało ono opatrzone w Wielkim słowniku języka polskiego definicją - 'niekomfortowa sytuacja (niewygoda, cierpienie fizyczne lub psychiczne, dolegliwość), którą ktoś musi znosić za to, że zrobił coś złego' - a w Kodeksie karnym rozumieniem $\mathrm{w}$ gruncie rzeczy zbliżonym - 'środek represyjny stosowany wobec osób, które popełniły przestępstwo lub w jakikolwiek inny sposób naruszyły normy prawne lub obyczajowe'. Co więcej, cechy składniowe przypisywane tej jednostce są realizowane $\mathrm{w}$ obu odmianach polszczyzny, por. _ _ kara $+\mathrm{CZEGO}+(z a \mathrm{CO})$

(19) Karę przepisania książeczki kapral Zasuń uznał za szczególnie wyrafinowana. NKJP

(20) Jeżeli ustawa nie stanowi inaczej, kara ograniczenia wolności trwa najkrócej miesiac, najdtużej 12 miesięcy; wymierza się ja w miesiacach. KK 34,1

Wydaje się więc, że brakuje wyraźnych odmienności pomiędzy funkcjonowaniem danego wyrażenia w obu subkodach szczególnie, gdy zaobserwujemy, że w prawostronnym kontekście w obu wypadkach pojawia się nazwa kary (np. śmierci, wygnania, ograniczenia wolności itp.). Podobnie de facto wygląda łączliwość lewostronna, gdzie przytoczony rzeczownik łączy się najczęściej z czasownikami, por. skazać na, grozić, wymierzyć itp.

4.2. Drugi zbiór jest tworzony przez wyrażenia obarczone odmiennością cech bądź formalno-znaczeniowych, bądź kolokacyjnych i zasadzającą się na dostosowywaniu wyrażenia polszczyzny ogólnej do kontek- 
stu prawnego ${ }^{3}$ [OGÓLNY $\Rightarrow$ PRAWNY]. Podstawą takiego przekształcenia jest określona jednostka - względnie ciąg jednostek - z polszczyzny ogólnej, której cechy zostały zmodyfikowane pod kątem funkcji prawnej. Przykładem takiego wyrażenia jest m.in. jednostka korzyść, której przypisuje się znaczenie 'coś dobrego dla kogoś, co jest wynikiem określonych działań albo określonej sytuacji' (WSJP) i strukturę składniową __ + $+k o-$ rzyść + (z CZEGO), por.

(21) Beata nie wnosiła do spółki niczego konkretnego, a czerpała z niej korzyści takie same jak ja czy Piotr. NKJP

Polszczyzna prawna z kolei przenosi środek ciężkości w wypadku znaczenia tej jednostki na dobra materialne, co wynika wprost $\mathrm{z}$ rozumienia tego pojęcia w Kodeksie cywilnym 'Kto bez podstawy prawnej uzyskał korzyść majątkową kosztem innej osoby, obowiązany jest do wydania korzyści w naturze, a gdyby to nie było możliwe, do zwrotu jej wartości' (KC 405). Z drugiej strony wyraźna jest w wypadku użyć prawnych zmiana struktury jednostki. Otóż pojęcie to bywa definiowane zazwyczaj w ciągach wielosegmentowych, korzyść majątkowa i korzyść osobista, co nie miało miejsca w wypadku polszczyzny ogólnej, por.

(22) Korzyściq majątkowa lub osobista jest korzyść zarówno dla siebie, jak i dla kogo innego. KK 115,4

(23) Kto wierzycielowi udziela lub obiecuje udzielić korzyści majątkowej za dziatanie na szkodę innych wierzycieli w związku z postępowaniem upadtościowym lub zmierzającym do zapobiegnięcia upadłości, podlega karze pozbawienia wolności do lat 3. KK 302,2

Mamy tu więc do czynienia z najczęściej wykorzystywanym mechanizmem modyfikacyjnym $\mathrm{w}$ tekstach prawnych. Termin prawny jest bowiem tworzony przez ciąg jednostek ogólnych, którym nadano na gruncie prawa nowe znaczenie, modyfikując przy okazji ich cechy formalno-znaczeniowe i kolokacyjne.

4.3. Pozostaje do rozważenia ostatnia grupa wyrażeń, a mianowicie ciągi, które wyjściowo funkcjonowały w polszczyźnie prawnej, ale zostały

3 Mechanizmy takiego dostosowywania zostały dokładnie zdefiniowane we wcześniejszym opracowaniu (zob. Gębka-Wolak, Moroz 2019). 
przeniesione na grunt polszczyzny ogólnej i tam zyskały odmienne cechy [PRAWNY $\Rightarrow$ OGÓLNY]. Przykładem może być wyrażenie przepadek, które jest $\mathrm{w}$ sposób naturalny łączone $\mathrm{z}$ subkodem prawnym $\mathrm{w}$ takim zakresie, że Wielki słownik języka polskiego przypisuje mu tylko znaczenie o takim nacechowaniu - 'zabranie komuś przez władze własności powiązanej w określony sposób z popełnieniem przestępstwa' i strukturę formalną o postaci __ + przepadek + CZEGO. W punkcie wyjścia rzeczownik ten wskazuje więc na pozbawienie kogoś rzeczy pochodzącej z przestępstwa, por.

(24) Przepadek grozi tylko tej części majątku oskarżonego, w której posiadanie wszedt od momentu popetnienia przestępstwa. NKJP

(25) W razie uiszczenia należności publicznoprawnej sąd może orzec przepadek przedmiotów tylko w warunkach określonych w art. 31 ß 3 pkt 2.. KKS 15,3

Sytuacja ta zmienia się jednak przy przejściu tego wyrażenia do polszczyzny ogólnej, gdzie jego łączliwość ulega zmianie, por.

(26) W pańskim wypadku oznacza to przepadek nadziei, w naszym utratę honorarium. NKJP

(27) Musimy mieć świadomość, co znaczy przepadek prezydenta, rolnicy nie dostaja urynkowienia. NKJP

\section{WNIOSKI}

Jak pokazują powyższe analizy, procedury orzekania o poprawności wyrażeń subkodów specjalistycznych, szczególnie subkodu prawnego, nie należą do problemów prostych. W punkcie wyjścia konieczne jest bowiem precyzyjne porównanie obu obiektów, zwracające uwagę na wszelkie odrębności natury zarówno formalnej, jak i semantycznej. Jedynie bowiem w taki sposób można jednoznacznie orzec, czy wyrażenie subkodu prawnego jest tą samą jednostką języka co ciąg z polszczyzny ogólnej, czy też jej wariantem, względnie odrębną jednostką leksykalną. Od tej decyzji zależy bowiem sposób dalszego procedowania i zgoda na wykorzystywanie mechanizmów ogólnych. Ich stosowanie jest bowiem nieskuteczne w sytuacji, gdy ciąg prawny stanowi niezależny byt leksykalny. 
Z drugiej jednak strony o normatywnej ocenie terminów prawnych winny decydować dwa istotne kryteria. Po pierwsze, ściśle określona i zweryfikowana struktura znaczeniowo-formalna, co powinno być uwidocznione w odpowiednim leksykonie prawnym, z drugiej zaś zakres łączliwości leksykalno-strukturalnej, której podlegają obiekty tej klasy. Byty takie winny być więc oceniane na podstawie niezależnych od polszczyzny ogólnej kryteriów. Z całą pewnością również nie należy wyciągać deprecjonujących wniosków jedynie na podstawie porównywania ich z wyrażeniami polszczyzny ogólnej.

\section{BIBLIOGRAFIA}

Chodun A., 2006, Leksyka tekstów aktów prawnych, „Ruch Prawniczy, Ekonomiczny i Socjologiczny", nr 4, s. 19-30.

Choduń A., 2007, Słownictwo tekstów aktów prawnych w zasobie leksykalnym wspótczesnej polszczyzny, Warszawa.

Czelakowska A., Kubicka E., 2017, O słownictwie specjalistycznym w leksykonach języka ogólnego na przykładzie wyrażeń prawnych i prawniczych, "Język Polski”, XCVII, z. 2, s. 43-59.

Gajda S., 1990, Wprowadzenie do teorii terminu, Opole.

Gębka-Wolak M., Moroz A., 2009, Poprawność a akceptowalność. Problemy teoretyczne, "Język Polski”, LXXXIX, z. 2, s. 124-134.

Gębka-Wolak M., Moroz A., 2019, Jednostka tekstu prawnego w ujęciu teoretycznym i praktycznym, Torun.

Grochowski M., 2017, Terminologia a jednostki leksykalne systemu ogólnego. O definiowaniu terminów w ustawach o nauce i szkolnictwie wyższym, w: Terminologia specjalistyczna w teorii i praktyce językoznawców słowiańskich, red. R. Przybylska, W. Śliwiński, Kraków, s. 11-28.

Hałas B., 1995, Terminologia języka prawnego, Zielona Góra.

Kieraś W., Kobyliński Ł., Ogrodniczuk M., 2018, Korpusomat - a tool for creating searchable morphosyntactically tagged corpora, "Computational Methods in Science and Technology" 24, 1, s. 21-27.

Lizisowa M. T., 2016, Komunikacyjna teoria języka prawnego, Poznań.

Łapa R., 2015, Język prawny w świetle analizy językoznawczej. Wybrane zagadnienia składniowe, Poznań.

Malinowski A., 2006, Polski język prawny. Wybrane zagadnienia, Warszawa.

Markowski A., 2005, Kultura języka polskiego: teoria, zagadnienia leksykalne, Warszawa.

Moroz A., 2014, Granice błędu - norma jezzykowa a teksty prawne, „Poznańskie Spotkania Językoznawcze", t. 28, s. 17-31.

Petzel J., 2011, Status lingwistyczny języka prawnego, w: Prawo, język, media, red. A. Mróz, A. Niewiadomski, M. Pawelec, Warszawa, s. 153-165. 
Przepiórkowski, A., M. Bańko, R. L. Górski i B. Lewandowska-Tomaszczyk (red.), 2012, Narodowy Korpus Języka Polskiego, Warszawa.

Saussure F., 2004, Szkice z językoznawstwa ogólnego, przeł., wstęp i red. nauk. M. Danielewiczowa, Warszawa.

Wróblewski B., 1948, Język prawny i prawniczy, Kraków.

Zajadło J., 2014, Terminologia łacińska w pracy wspótczesnego prawnika: retoryczny ozdobnik czy warsztatowa konieczność, w: Kultura języka polskiego w praktyce prawniczej, red. D. Kala, E. Kubicka, Bydgoszcz, s. 112-131.

Zieliński M., 1999, Języki prawne i prawnicze, w: Polszczyzna 2000. Orędzie o stanie języka na przełomie tysiącleci, red. W. Pisarek, Warszawa, s. 50-74.

Żmigrodzki P., Bańko M., Batko-Tokarz B., Bobrowski J., Czelakowska A., Grochowski M., Przybylska R., Waniakowa J., Węgrzynek K., 2018, Wielki stownik języka polskiego PAN: geneza, koncepcja, zasady opracowania, Kraków.

Żurowski S., 2015, Terminologia łacińska w pracy wspótczesnego prawnika - polemicznie, w: Język - urząd - prawo, red. M. Czachorowska, Bydgoszcz, s. 211-219.

\title{
LEGAL TERMINOLOGY IN A NORMATIVE ASPECT
}

\begin{abstract}
This text deals with the problem of procedures for adjudication on the correctness of terminological expressions used in legal texts. In particular, it argues about the need of distinguishing three types of units - those compatible with general units, motivated by general units, and affecting the form and the meaning of general units. Expressions, that belong to each of the above distinguished types, require separate standardisation procedures. Apart from fundamental considerations, the issue of the status of terminological expressions in legal texts as well as their relation to general units is discussed.
\end{abstract}

Key words: legal language, source of legal lexis, specialist vocabulary, terms 